Through the letters, recordings and narrative emerges a story that illuminates the working life of a scientist in a detailed and open way that has seldom, if ever, been done before. Unlike The Double Helix, An Imagined World contains little glamour, much toil, many failures, much anguish and no prizes. It is, in a word, realistic. Whether that makes for interesting reading is a matter of taste. Certainly for the working scientist there will be few surprises, but there may be reflections, both pleasant and not so pleasant, to be seen in the mirror of Anna Brito's progress. For the non-scientist who does not realize just how great a travesty of the making of a discovery is the usual account given in a scientific paper, the book is bound to come as an eye-opener.

It would be hard, however, to claim that Anna Brito's experiences were particularly typical. Her first, and arguably most important, discovery certainly came about in an unusual way. She found herself in a London laboratory, unable to speak much English, having neither skills nor ideas to offer and altogether a rather unwanted visitor. Her supervisor, somewhat in desperation, gave her a large collection of sections of mice to examine through a microscope. Against all the odds she noticed something both original and interesting. Her observation amounted to the discovery that $T$-lymphocytes and B-lymphocytes have predilections for separate zones of tissues.

In the years that followed, Anna Brito pursued her discovery of what she called "ecotaxis" and developed the idea that certain diseases were associated with wrongly located lymphocytes. This condition she called "ecotaxopathy", a term guaranteed to turn purple the faces of many immunologists. Clearly not a lady to be thrown off course by such reactions or by what, to many, would surely be an unnerving number of grant refusals, her research continued in the same vein throughout the period covered in the book.

Much of what is recounted rings true; for example, the long periods Anna Brito spends reading around her subject hoping to place her observations into a broader context. Other features of her laboratory life seem less convincingly told. Only twice, for example, is there any mention of her having any scientific competitors. This is either true and untypical, or untrue and misleading, given the extent to which competition drives so many scientists.

The chief virtue of the book is that it recounts in detail the thoughts and actions of a scientist brave enough to be open about her mistakes and failures and to bare many of her thoughts, despite the risk that some might look naive at the time and worse in retrospect. But the book fails to shed much light on the process of scientific discovery or to sustain interest for one simple reason; as it happens, nothing that I could classify as a substantial discovery emerges during the period covered in the book.

Finally, potential readers might be attracted by two puzzles. The first, not too taxing, is the real identity of Anna Brito. The second, perplexing, is why, given the circumstances of the initial discovery that set her on the pilgrimage of research, Brito can later say: "I can't stand people who just put everything together and try to see what happens - who don't think before doing an experiment . . I I could never do science like that"?

Peter Newmark is Deputy Editor of Nature.

\title{
Will the real Beaker Folk please stand up?
}

\section{Colin Burgess}

The Beaker Folk: Copper Age Archaeology in Western Europe. By Richard J. Harrison. Pp.176. ISBN 0-500-02098-1. (Thames \& Hudson: 1981.) $£ 12, \$ 19.95$.

"BEAKER Folk", like the Wee Folk, exist in the mind of the beholder, and Dr Harrison is as uncertain in his attitude to "Beaker Folk" as most of us are about fairies. His last chapter, "Was there a 'Beaker Folk?'," was eminently sensible, and his conclusion that they "have no substance as a special population group", and that the Bell Beaker phenomenon began "as a fashion in fine pottery", would meet with widespread approval among students of the subject.

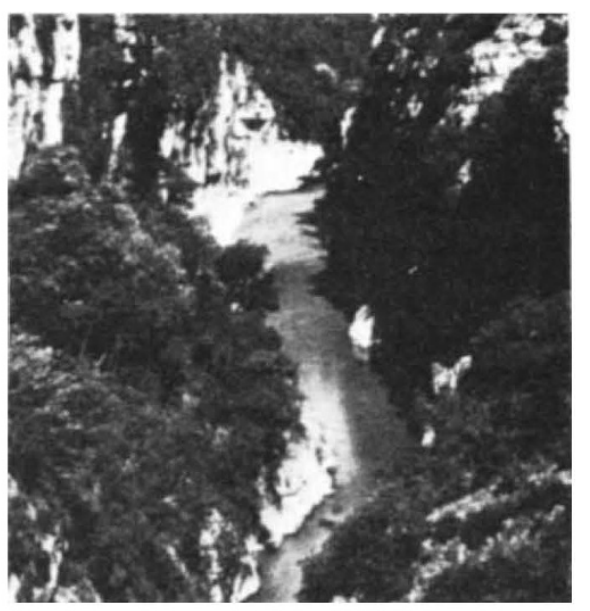

Gorge of the River Verdon in Provence, "an exceptionally interesting site',.

Unfortunately, this attitude does not square with the contradictions in his preceding six chapters. The author claims in several places not to believe in "Beaker Folk", but clearly finds it difficult to erase them from his subconscious. His inner confusion will leave the reader feeling profoundly uncomfortable, because it is obtrusive throughout: to quote from the jacket, 'the so-called 'Beaker Folk' were not a separate, well-defined community, but constituted more of an influence or movement", yet in the next sentence "They appear to have been instrumental in introducing metal technology", and their arrival "coincided with major changes in the structure of primitive society". Such ambivalence left me wondering at the end whether the author had experienced a late change of heart about "Beaker Folk", and been forced to take a scalpel to his text; or perhaps it is simply that he, like most of us, finds it difficult to adjust to a world without "Beaker Folk".

In many ways, Harrison engineers his own downfall. On p.13 he complains that "One bad habit which many archaeologists have had is to abstract beakers from their local settings and study them as something alien and isolated', which is exactly what has bedevilled study of this period in Europe, and is exactly the mistake this book perpetuates. For sadly, Harrison is largely concerned with his title, The Beaker Folk, and hardly at all with his subtitle, Copper Age Archaeology in Europe. But until the former is strictly subordinated to the latter, understanding of this exciting phase of European prehistory will advance very little.

There is a fundamental controversy about Beakers at the moment, and it should therefore be a priority in a work such as this to begin with a fair statement of the issues. As it is, for much of the book until the last chapter in fact - Harrison skates over the difficult question of Beaker interpretations with brief, throw-away allusions, and in so doing is hardly fair to those who have been trying to open up the whole question to review. For example, on p. 11 he is decidedly disparaging about the suggestion that Beakers may have been central to a beer drinking cult, but on p.15 they may "have been status symbols . . perhaps on account of a special drink", and on p.69"Bell Beakers could also have derived their importance from their contents, such as beer, mead ...'. If he looks again at what S.J. Shennan and I wrote in British Archaeological Reports in 1976 , he will see that our concern was not to set up alternative models to explain Beakers, but to show that there are explanations, other than ethnic ones, which will fit the evidence. Harrison, like some others, has seized on the evocative peyote/beer suggestion, but does not mention the equally relevant Butt Beaker analogy.

The author's preoccupation with the Beaker aspects of this phase of prehistory results in much of the book being a rather dreary regional catalogue of contexts and sites in which Beakers occur. How much more illuminating it would have been had he remembered his sub-title, and con- 
sidered the local background. As it is the Beakers too often float in a vacuum. The reader will find it nearly impossible to grasp how they relate to regional cultural developments, for frequent allusions make it clear that Beakers were absorbed by local populations and adapted to suit local circumstances. Thus Myrhøj in Jutland is a "Bell Beaker settlement" (p.35), but only one house had Beakers. Local Late Neolithic pottery dominates, but where does it fit in? In Hungary, the Beaker is intrusive in local Vučedol contexts, while over the Eastern Beaker province as a whole "between $80 \%$ and $90 \%$ of all pottery found in Bell Beaker graves [sic] is not actually of a beaker shape at all [my italics], but small cups, jugs, bowls and jars". So why should these be "Bell Beaker graves" and Myrhøj a "Bell Beaker settlement"?

What is needed here, if ever we are to make sense of the Copper Age in Europe, is a radical change in thinking. These are not "Bell Beaker" graves and settlements, but the graves and settlements of whatever local cultural group is involved, which happen to incorporate Beakers and Beaker influence to varying degrees. Usually Harrison at least acknowledges a local cultural element, for example in southern France (pp.114-116), and especially in Italy (p.123), where recent discoveries offer a good chance of putting Beakers into proper perspective. Alas, in Britain and Ireland, Harrison opts for the traditional Beaker invaders. "Bell Beaker settlements", as at Newgrange and Knowth, are mentioned without making it clear that only a fraction of their pottery is classic Beaker; a lot of it is decidedly sui generis, and the rest local in character. For me, the treatment of Britain is particularly disappointing: the author fails to examine objections to a distinct Beaker physical type; he does not scrutinize critically the socalled Beaker innovations; and he appears not to appreciate the supreme importance of the Lanting and Van der Waals regional approach, not just for British Beakers, but for later British prehistory generally.

It would be churlish not to compliment the author on his choice of illustrations, which make clear the skill and patience which went into producing Beakers; and as a panoramic view of the variety of regional Beaker styles this book will be invaluable. But Harrison's aim is to "give an intelligible account of the Copper Age in Western Europe" (p.6) and he does not seriously attempt the task. It is a perilous time to write on the Beaker phenomenon, but suicidal not to have a clear idea in one's own mind beforehand of what Beakers are all about. I confess that I would not be so rash as entirely to dismiss the Wee Folk; but I have no such qualms about the "Beaker Folk",

Colin Burgess is Staff Tutor in Archaeology Department of Adult Education, University of Newcastle upon Tyne, and author of The Age of Stonehenge (Dent, 1980).

\section{Mummies: new light on ancient societies}

\section{A. Rosalie David}

An X-Ray Atlas of the Royal Mummies. Edited by James E. Harris and Edward F. Wente. Pp.403. ISBN 0-2263-1745-5. (Chicago University Press: 1980.) $\$ 55, £ 33$. Mummies, Disease and Ancient Cultures. Edited by Aidan and Eve Cockburn. Pp.360. ISBN 0-521-23020-9.(Cambridge University Press: 1980.) £25, \$45.95.

GRAFTON Elliot Smith, Armand Ruffer and Alfred Lucas led the field in the application of their disciplines - anatomy, histology and chemistry - to the study of ancient Egyptian mummified remains in the early part of this century. Since then, there has been a continuing interest in the use of medical and scientific techniques to amplify historical and literary knowledge of family relationships, the existence of disease, living conditions and funerary practices in this ancient civilization. Recent technological advances have encouraged further multi-disciplinary research, and the study of mummies has provided the Egyptologist with new information.

The discovery of the Egyptian royal mummies of the New Kingdom period (c. $1675-950 \mathrm{BC}$ ) was an archaeological find of considerable significance. The pharaohs and their queens, buried with great ceremony in rock-cut tombs at Thebes in Upper Egypt, were soon disturbed by robbers; their tombs were plundered and their mummies stripped of precious amulets. The high-priests of the god Amon re-buried many of these royal mummies in two resting places - the shaft of a tomb near Deir el-Bahri and a side chamber in a King's tomb in the Valley of the Kings - in the vicinity of Thebes. Here, they remained undisturbed until the chance discovery of the two caches in AD 1871 and AD 1898.

The mummies were subsequently removed to the Cairo Museum, where they were unwrapped and investigated by archaeologists and anatomists in 1889 and in 1912, when G. Elliot Smith produced his definitive anatomical work entitled The

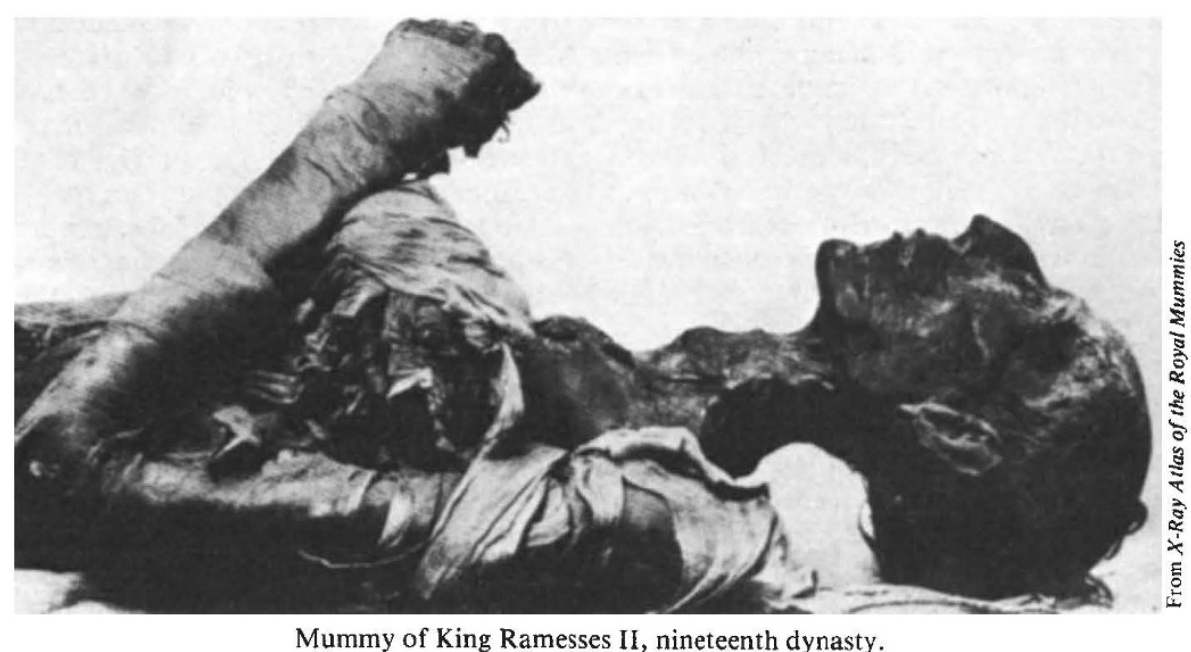

Royal Mummies. This included the examination of kings, queens, princes, princesses, priests and some unidentified individuals. However, having the opportunity to examine only one of these mummies with radiographic techniques, he stated that ". . . examination with the aid of X-rays would, no doubt, have provided much additional information and $I$ hope this will be done at some future time . . .".

This opportunity did not arise until 1967, when the University of Michigan, which had previously collaborated with Alexandria University in a radiographic survey of the skulls of an ancient Nubian people, was invited by the Egyptian authorities to $\mathrm{X}$-ray the royal mummies in the Cairo Museum.

Their aims were to add to historical and literary sources relating to the chronology of this period and to the lengths of the rulers' reigns; to assess the health of each individual; to check the reality of the royal sculpture and art forms against the physical evidence of the mummies; and, using a portable X-ray cephalometer, to determine the craniofacial variations and the degree of physical heterogeneity evident in the pharaohs and queens of the New Kingdom.

The Atlas provides the long-awaited reference work (a popular interim account by J. E. Harris and K. R. Weeks, X-Raying the Pharaohs, was by published in 1973 by Charles Scribner's Sons). It does not give a detailed description of each mummy, but, in addition to the illustrative material, uses a series of self-contained chapters to highlight features of this unique collection. The chapters reflect the individual interests of the multi-disciplinary team, and include techniques of mummification, the practice of medicine and dentistry in ancient Egypt, evidence of physical and dental disease in the royal mummies, radiological techniques and findings, the geneaology of the Royal Family and craniofacial variation, pharaohs (here, Egyptological and and the age at death of the New Kingdom 